The families studied in the present work yield $\frac{V_{A}}{V_{P}}$

for post-phenobarbitone phenylbutazone half-life corrected for height. These results are clearly of much the same order. The same genes do not control the two characters, since the postphenobarbitone phenylbutazone half-life data have been adjusted to a standard height.

\section{Therapeutic Implications}

Some drugs are known to show a correlation between plasma level and (1) therapeutic effect and (2) occurrence of toxic (or adverse) effects. Bruck et al. (1954) showed that various toxic effects were more common in patients receiving phenylbutazone whose blood levels exceeded $100 \mu \mathrm{g} . / \mathrm{ml}$. than in those with concentrations below this level. On the other hand, subjective improvement in rheumatoid arthritics was more frequent above blood phenylbutazone concentrations of $50 \mu \mathrm{g}$. $/ \mathrm{ml}$. than below this level. The variability in phenylbutazone half-life is therefore relevant in regard to the consequences of phenylbutazone therapy. It is also relevant that for a pharmacological phenomenon in a population of patients, $V_{P}$ may be increased by additions to $\mathrm{V}_{\mathrm{E}}$ owing, for example, to disease, differing modes of administration, etc. On the other hand, $V_{G}$ cannot be diminished. Thus possibly in the future attention to the variability between persons may result in the development of improved therapeutics.

We wish to thank the North-West Cancer Research Fund for a Leukaemia Research Fellowship held by J.A.W. during the time this research was performed; the United Liverpool Hospitals Research Committee and the Nuffield Foundation for generous financial support; Miss M. F. Bullen, S.R.N., of the department of medicine, for help in locating and testing many family members; and Mr. M. C. K. Tweedie, of the department of medicine, for special statistical advice. The following family doctors were most helpful in locating co-operative families for the experiment: Dr. P. J. J. Wren, Chorley; Dr. R. A. Yorke, Maghull, Lancs; Drs. R. Hardman and N. Shieff, Liverpool; and Dr. T. B. Benson, Helsby, Cheshire. Geigy Pharmaceuticals (U.K.) Limited donated a sample of pure phenylbutazone for use as a reference standard.

REFERENCES

Aggeler, P. M., and O'Reilly, R. A. (1969). Journal of Laboratory and Clinical Medicine, 74, 229.

Bailey, N. T. J.' (1959). Statistical Methods in Biology. London, English

Bönicke, R., and Lisboa, B. P. (1957). Naturwissenschaften, 44, 314.

Bruck, E., Fearnley, M. E., Meanock, I., and Patley, H. (1954). Lancet, 1, 225.

Burns, J. J., and Conney, A. H. (1965). Proceedings of the Royal Society of Medicine, 58, 955

Burns, J. J., et al. (1953). Fournal of Pharmacology and Experimental Therapeutics, $109,346$.

Burns, J. J., et al. (1955). Fournal of Pharmacology and Experimental Therapeutics, 113, 481 .

Cho, A. K., Hodshon, B. J., and Brodie, B. B. (1970). Biochemical Pharmacology, 19, 1817.

Cucinell, S. A., Conney, A. H., Sansur, M., and Burns, J. J. (1965). Clinical Pharmacology and Therapeutics, 6, 420.

Davies, D. S. (1970). Acta Pharmacologica et Toxicologica. In press.

Drabkin, D. L. (1959). Perspectives in Biology and Medicine, 2, 473.

Falconer, D. S. (1960). Introduction to Quantitative Genctics. Edinburgh, Oliver and Boyd.

Fisher, R. A. (1921). Transactions of the Royal Society of Edinburgh, 52, 399. Fouts, J. R. (1961). Biochemical and Biophysical Research Communications, 6, 373 .

Galton, Sir F. (1889). Natural Inheritance. London, Macmillan.

Levi, A. J., Sherlock, S., and Walker, D. (1968). Lancet, 1, 1275.

Mannering, G. J. (1968). In Selected Pharmacological Testing Methods, ed. A. Burger, p. 51. London, Arnold.

Remmer, H., and Merker, H. J. (1965). Annals of the New York Academy of Sciences, 123, 79 .

Vesell, E. S., and Page, J. G. (1968). Science, 159, 1479.

\title{
Autonomic Control of Insulin Secretion and the Treatment of Heart Failure
}

\author{
P. A. MAJID, ${ }^{*}$ M.B., B.S., M.R.C.P. ; C. SAXTON,† M.B., CH.B., B.SC. ; J. R. W. DYKES, $\ddagger$ M.B., CH.B., B.SC. \\ M. C. GALVIN, $囚$ M.B.; CH.B. ; S. H. TAYLOR, $\|$ M.B., B.SC., M.R.C.P.
}

$S^{\mathrm{u}}$ mmary: To investigate the role of the autonomic nervous system in controlling insulin secretion 13 normal subjects and 5 patients with heart failure underwent insulin secretion tests. Alpha-adrenergic stimulation and beta-receptor blockade significantly depressed the secretion of insulin in response to intravenous tolbutamide in normal subjects, while both alpha-blockade and beta-stimulation significantly increased the insulin secretion response in both normal subjects and patients in heart failure. Parasympathetic stimulation and blockade had no significant effect on the insulin secretion response. These findings suggest that drugs that block the alphaadrenergic receptors or stimulate the beta-adrenergic receptors by their ability to counteract the insulin suppression resulting from increased sympathetic nervous activity may play a vital metabolic part in the deranged metabolism of the failing heart in addition to their direct haemodynamic benefits.

* Senior Wellcome Foundation Research Fellow; Honorary Lecturer in Medicine, University of Leeds.

† Leeds Regional Hospital Board Research Fellow.

$\neq$ Lecturer in Chemical Pathology, University of Leeds.

$\$$ Imperial Chemical Industries Research Fellow.

Senior Lecturer in Medicine, University of Leeds; Consultant Physician to the United Leeds Hospitals and the Leeds Regional Hospital Board.

\section{Introduction}

The normal insulin secretion response to glucose and tolbutamide is suppressed in patients with severe power failure of the heart, whether this is due to cardiogenic shock after myocardial infarction (Allison et al., 1969; Taylor et al., 1969), severe congestive heart failure (Sharma et al., 1970), or pumping failure after open-heart surgery (Majid et al., 1970). Evidence has suggested that one of the major factors responsible for this suppression of insulin secretion was the greatly increased sympathetic stimulation found in such patients (Taylor et al., 1969; Majid et al., 1970; Sharma et al., 1970). The present investigation was therefore directed to examining the effect of pharmacological stimulation and blockade of the sympathetic and parasympathetic receptors on insulin release from the pancreas of normal subjects and patients in severe heart failure.

\section{Methods}

Thirteen volunteer normal male subjects, with a mean age of 35 (range 20-54) years, and five patients, three men and two women, aged 46,50 , and 58 , and 32 and 43 years, respectively, in severe heart failure were studied. The purpose of the study was explained in detail to all the subjects and their 
written consent obtained.

Of the five patients the heart failure was due to chronic rheumatic heart disease in three, to hypertension in one, and to advanced ischaemic heart disease in one. All were bedridden and had radiographic evidence of generalized cardiac enlargement and pulmonary venous congestion, a raised jugular venous pressure, enlargement of the liver, and peripheral oedema. Clinically, all had responded poorly to treatment with digitalis, diuretics, and potassium.

\section{Design of Investigation}

All subjects underwent a control and one test study; seven of the 13 normal subjects and two of the five patients underwent an additional test study (Table I).

TABLE I.-Programme of Investigation

\begin{tabular}{|c|c|c|c|c|c|}
\hline & Day 1 & Day 2 & & Day 3 & \\
\hline Normal subjects. . & Control study (13) & $\begin{array}{l}\text { a-Stimulation } \\
\alpha \text {-Blockade } \\
\beta-\text {-Blockade } \\
\text { Methacholine }\end{array}$ & $\begin{array}{l}\text { (4) } \\
(1) \\
(4) \\
(4)\end{array}$ & $\begin{array}{l}\text { a-Blockade } \\
\text { B-Stimulation } \\
\text { Atropine }\end{array}$ & $\begin{array}{l}\text { (1) } \\
\text { (2) }\end{array}$ \\
\hline Heart failure & Control study (5) & $\begin{array}{l}\alpha \text {-Blockade } \\
\beta \text {-Stimulation }\end{array}$ & $\begin{array}{l}\text { (4) } \\
\text { (1) }\end{array}$ & $\begin{array}{c}\boldsymbol{\beta} \text {-Stimulation } \\
\boldsymbol{\alpha} \text {-Blockade }+ \\
\boldsymbol{\beta} \text {-Stimulation }\end{array}$ & $\begin{array}{l}\text { (1) } \\
\text { (1) }\end{array}$ \\
\hline
\end{tabular}

Number of patients in each study in parentheses.

\section{Insulin Secretion Test}

The insulin secretion test was based on the known potency of intravenous tolbutamide to release preformed insulin from the beta-cells of the pancreas (Seltzer, 1962). Studies in normal subjects have shown that the peak rise in plasma insulin occurs within the first few minutes after the tolbutamide injection and that the plasma insulin curve is nearly complete after 30 minutes (Maingay et al., 1967; Saxton et al., 1970). The test was carried out in the morning following a 12-hour fast. After control samples of venous blood had been taken, $1 \mathrm{~g}$. of tolbutamide was injected intravenously over 10 seconds. Further venous blood samples for plasma insulin and blood glucose measurements were taken at $1,2,5,10,15$, and 30 minutes after the injection.

\section{Dose and Method of Administration of Drugs}

(a) Methoxamine is a potent stimulator of the alphaadrenergic receptors. A priming intravenous injection of 5 mg. was followed by a constant infusion of $0.5-1 \mathrm{mg} . / \mathrm{min}$. Intra-arterial pressure was continuously recorded and the dose adjusted to maintain the mean systemic arterial pressure at about $30 \mathrm{~mm}$. $\mathrm{Hg}$ above the control value. Tolbutamide was injected 30 minutes after the start of the methoxamine infusion, which was continued throughout the remaining 30 minutes of the insulin secretion test.

(b) Phentolamine, which is a rapid and powerful blocker of the alpha-adrenergic receptors, was given by continuous intravenous infusion of $1-2 \mathrm{mg}$./ $\mathrm{min}$. Intra-arterial pressure was continuously recorded and the dose adjusted to maintain the mean systemic arterial pressure at about $30 \mathrm{~mm}$. $\mathrm{Hg}$ below the control value. Tolbutamide was injected 30 minutes after the start of the phentolamine infusion, which was continued throughout the remaining 30 minutes of the insulin secretion test.

(c) Isoprenaline, a potent stimulator of the beta-adrenergic receptors, was given by continuous intravenous infusion of 5 $10 \mu \mathrm{g} . / \mathrm{min}$. The heart rate and rhythm were continuously monitored by an electrocardiograph, and the dose was adjusted to maintain the heart rate at about 150 beats per minute. Tolbutamide was injected 15 minutes after the start of the isoprenaline infusion, which was continued throughout the remaining 30 minutes of the insulin secretion test. (d) Propranolol, a powerful blocker of the beta-adrenergic receptors, was given as a bolus intravenous injection in a dose of $0.2 \mathrm{mg} . / \mathrm{kg}$. body weight. This dose results in complete or nearly complete beta-adrenergic blockade in man (Jose and Taylor, 1969; Taylor et al., 1970a). Tolbutamide was injected 30 minutes after the propranolol had been given.

(e) Methacholine is a potent parasympathetic stimulator with a preponderance of muscarinic effects; it is of greater selectivity and duration of action than acetylcholine (Payne and Kay, 1962; Koelle, 1965). It was given by continuous intravenous infusion of $0.4 \mathrm{mg}$. $/ \mathrm{min}$. The heart rate and rhythm and blood pressure were continuously monitored. This dose uniformly brought a fall in heart rate of $10-20$ beats per minute, a reduction of systolic blood of $10 \mathrm{~mm}$. $\mathrm{Hg}$, increased salivation, and widespread flushing of the skin. Tolbutamide was injected 15 minutes after the start of the infusion, which was continued throughout the remaining 30 minutes of the insulin secretion test.

(f) Atropine is a powerful blocker of parasympathetic receptors. A priming intravenous injection of $0.02 \mathrm{mg} . / \mathrm{kg}$. was given, followed by a constant intravenous infusion of $\mathbf{0 . 1}$ $\mathrm{mg}$./min. The heart rate and rhythm were continuously monitored by an electrocardiograph; the dose used uniformly resulted in an increase in heart rate to about $120-130$ beats per minute. Tolbutamide was injected 30 minutes after the start of the infusion, which was continued throughout the remaining 30 minutes of the insulin secretion test.

\section{Laboratory Techniques}

Intra-arterial pressure was transduced, calibrated, and recorded as previously described (Taylor et al., 1970b). The blood glucose concentration was measured in duplicate by an AutoAnalyzer glucose oxidase method (Morley et al., 1968); at a blood glucose concentration of $106 \mathrm{mg} . / 100 \mathrm{ml}$. the coefficient of variation was $4.6 \%$. Immunoreactive insulin was measured by a double-antibody radioimmunoassay method (Hales and Randle, 1963), the reagents and Oxoid membrane filters used being supplied by the Radiochemical Centre, Amersham. The standards were based on crystalline bovine insulin, a calibration range $0-500$ micro-units $(\mu \mathrm{u}.) / \mathrm{ml}$. being used. The standard deviation between duplicates in the concentration ranges $0-45,50-99,100-199$, and 200 or more $\mu \mathrm{u} . / \mathrm{ml}$. was $\pm 3.3, \pm 7.4, \pm 9.7$, and $\pm 12.3 \mu \mathrm{u} . / \mathrm{ml}$., respectively. All biochemical measurements were made in duplicate.

\section{Measurements and Calculations and Statistical Analysis}

The insulin secretion response was measured quantitatively by calculating the separate areas under the plasma curve for the first 10 minutes and for the whole 30 minutes after the

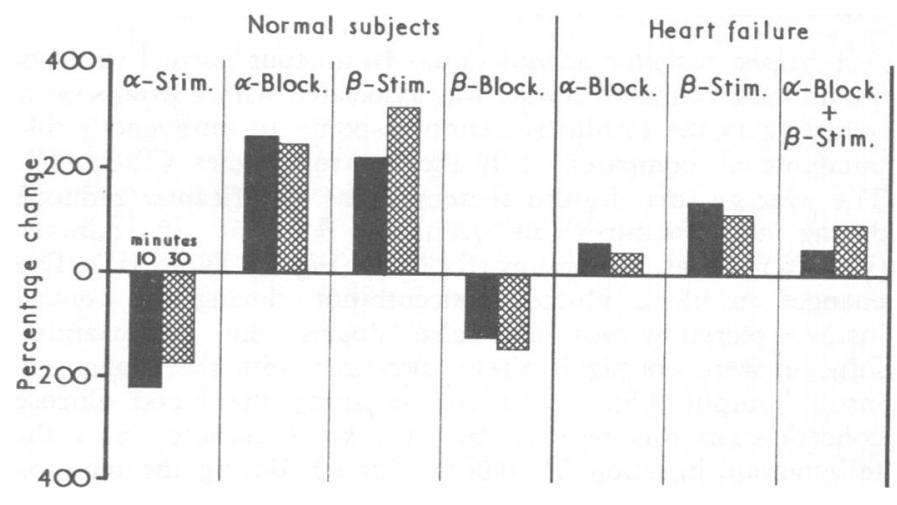

Fig. 1.- Total insulin secretion response to intravenous tolbutamide during sympathetic stimulation and blockade in normal subjects and patients in 
TABLE II.-Summarized Data of Insulin-secretion Test in Normal Subjects (Insulin in $\mu \mathrm{u} . / \mathrm{ml}$. Glucose in mg./100 ml.)

\begin{tabular}{|c|c|c|c|c|c|c|c|c|}
\hline & & \multicolumn{7}{|c|}{ Time (Minutes) after Injection of Tolbutamide } \\
\hline & & 0 & 1 & 2 & 5 & 10 & 15 & 30 \\
\hline \multirow{2}{*}{ Control (4) } & $\int$ Insulin $\ldots$ & $50 \pm 19(37)$ & $113 \pm 48(97)$ & $208 \pm 49(98)$ & $197+69(137)$ & $154 \pm 53(105)$ & $108 \pm 25(43)$ & $70 \pm 34(69)$ \\
\hline & Glucose .. & $78 \pm 3(7)$ & $73 \pm 1(3)$ & $74 \pm 3(6)$ & $73 \pm 1(3)$ & $70 \pm 4(7)$ & $58 \pm 2(5)$ & $36.6(12)$ \\
\hline \multirow{2}{*}{ a-Stimulation } & $\{$ Insulin $\ldots$ & $27 \pm 9(18)$ & $49 \pm 30(59)$ & $72 \pm 40(79)$ & $68 \pm 32(64)$ & $58 \pm 27(55)$ & $55+23(47)$ & $21 \pm 4(8)$ \\
\hline & Glucose .. & $80 \pm 4(8)$ & $81 \pm 2(4)$ & $84 \pm 1(2)$ & $82 \pm 1(2)$ & $76 \pm 3(6)$ & $67 \pm 4(7)$ & $52 \pm 8(16)$ \\
\hline \multirow{2}{*}{ Control (2) } & $\{$ Insulin $\ldots$ & $20 \pm 3(4)$ & $30 \pm 3(4)$ & $102+49(69)$ & $90 \pm 30(42)$ & $87 \pm 23(32)$ & $69 \pm 29(41)$ & $35 \pm 8(11)$ \\
\hline & Glucose . & $83 \pm 12(17)$ & $83 \pm 11(16)$ & $83 \pm 9(12)$ & $82 \pm 10(13)$ & $77 \pm 11(15)$ & $68 \pm 12(16)$ & $47 \pm 11(15)$ \\
\hline \multirow{2}{*}{ a-Blockade } & Insulin $\ldots$ & $71 \pm 31(44)$ & $357 \pm 59(83)$ & $366 \pm 84(118)$ & $294 \pm 111(156)$ & $262 \pm 105(148)$ & $212 \pm 100(141)$ & $205 \pm 77$ (109) \\
\hline & Glucose .. & $77 \pm 5(6)$ & $78 \pm 8(11)$ & $78 \pm 5(7)$ & $76 \pm 4(5)$ & $77 \pm 2(3)$ & $63 \pm 5(7)$ & $46 \pm 16(22)$ \\
\hline \multirow{2}{*}{ Control (2) } & $\{$ Insulin $\ldots$ & $23 \pm 6(8)$ & $30 \pm 3(4)$ & $155 \pm 5(7)$ & $114 \pm 6(8)$ & $103 \pm 7(9)$ & $59 \pm 40(56)$ & $23 \pm 5(6)$ \\
\hline & Glucose .. & $75 \pm 3(4)$ & $72 \pm 2(3)$ & $73 \pm 0(0)$ & $73 \pm 1(2)$ & $73 \pm 7(9)$ & $56 \pm 3(4)$ & $30+0.5(1)$ \\
\hline \multirow{2}{*}{$\beta$-Stimulation } & $\{$ Insulin $\ldots$ & $40 \pm 20(28)$ & $260 \pm 84(120)$ & $395 \pm 91(128)$ & $333 \pm 5$ & $328 \pm 36(51)$ & $251 \pm 7(10)$ & $140 \ldots 11(16)$ \\
\hline & Glucose .. & $55 \pm 14(19)$ & $68 \pm 7(9)$ & $70 \pm 7(10)$ & $75 \pm 11(16)$ & $76 \pm 11(16)$ & $72 \pm 9(12)$ & $58 \pm 13(18)$ \\
\hline \multirow{2}{*}{ Control (4) } & $\{$ Insulin $\ldots$ & $27 \pm 4(8)$ & $219 \pm 63(125)$ & $479 \pm 158(274)$ & $363 \pm 147(294)$ & $292 \pm 126$ & $217 \pm 72(145)$ & $121 \pm 39(78)$ \\
\hline & Glucose .. & $77 \pm 8(16)$ & $79 \pm 8(16)$ & $79 \pm 8(15)$ & $73 \pm 6(12)$ & $66 \pm 5(11)$ & $58 \pm 11(22)$ & $55 \pm 8(17)$ \\
\hline \multirow{2}{*}{ B-Blockade } & $\{$ Insulin $\ldots$ & $28 \pm 10(18)$ & $170 \pm 60(121)$ & $202 \pm 86(171)$ & $176 \pm 92(184)$ & $135 \pm 77(153)$ & $107 \pm 59(119)$ & $48 \pm 19(38)$ \\
\hline & Glucose ... & $71 \pm 4(8)$ & $76 \pm 7(14)$ & $75 \pm 6(13)$ & $74 \pm 6(12)$ & $70 \pm 7(13)$ & $64 \pm 6(12)$ & $53 \pm 6(13)$ \\
\hline \multirow{2}{*}{ Control (4) } & $\{$ Insulin $\ldots$ & $18 \pm 3(6)$ & $37 \pm 12(23)$ & $111 \pm 54(108)$ & $107 \pm 37(74)$ & $109 \pm 32(63)$ & $77 \pm 18(36)$ & $34 \pm 4(7)$ \\
\hline & Glucose .. & $67 \pm 4(9)$ & $64 \pm 4(8)$ & $65 \pm 4(8)$ & $65 \pm 3(7)$ & $59+3(6)$ & $53+3(6)$ & $34 \pm 5(9)$ \\
\hline \multirow{2}{*}{ Methacholine } & $\int$ Insulin $\ldots$ & $24 \pm 8(15)$ & $46 \pm 19(38)$ & $110 \pm 29(57)$ & $128 \pm 33(65)$ & $90 \pm 27(55)$ & $78 \pm 27(55)$ & $28 \pm 10(20)$ \\
\hline & Glucose .. & $68 \pm 3(6)$ & $68 \pm 4(7)$ & $69+3(6)$ & $69+3(6)$ & $63 \pm 3(7)$ & $55 \pm 6(12)$ & $40 \pm 5(11)$ \\
\hline \multirow{2}{*}{ Control (4) } & Insulin $\ldots$ & $18 \pm 3(6)$ & $37 \pm 12(23)$ & $111 \pm 54(108)$ & $107 \pm 37(74)$ & $109 \pm 32(63)$ & $77 \pm 18(36)$ & $34 \pm 4(7)$ \\
\hline & Glucose .. & $67 \pm 4(9)$ & $64 \pm 4(8)$ & $65 \pm 4(8)$ & $65 \pm 3(7)$ & $59 \pm 3(6)$ & $53 \pm 3(6)$ & $34 \pm 5(9)$ \\
\hline \multirow{2}{*}{ Atropine } & $\{$ Insulin $\ldots$ & $17 \pm 2(4)$ & $50 \pm 6(12)$ & $149 \pm 46(92)$ & $113 \pm 39(79)$ & $77 \pm 28(57)$ & $65 \pm 28(57)$ & $31 \pm 6(12)$ \\
\hline & Glucose .. & $68 \div 3(6)$ & $65 \pm 7(13)$ & $69 \pm 5(9)$ & $70 \pm 2(4)$ & $58 \pm 6(13)$ & $54 \pm 5(10)$ & $42 \pm 6(13)$ \\
\hline
\end{tabular}

Number of patients in each study in parentheses. Data expressed as mean \pm variance of mean with standard deviation of observations in parentheses.

tolbutamide test. The standard error of duplicate estimations of the total insulin secretion following intravenous tolbutamide was estimated from the measurements made on consecutive days in 10 normal subjects (Saxton et al., 1970). At 10 and 30 minutes the standard error of the estimate was 0.111 and $0.255 \mathrm{unit} / \mathrm{ml}$. min., respectively. With a normal distribution of the error, at 10 minutes the differences in area of the insulin secretion curve greater than $0.405,0.635$, and 1.081 units $/ \mathrm{ml}$. min. are significant at confidence levels of 5,1 , and $0.1 \%$, respectively. At 30 minutes, differences in area greater than $0.927,1.454$, and $2.477 \mathrm{units} / \mathrm{ml}$. min. indicate similar levels of confidence. Statistical analyses were based on orthodox methods (Fisher, 1946).

\section{Results}

\section{Studies in Normal Subjects}

(1) Alpha-receptor Stimulation.-In all four normal subjects the infusion of methoxamine was associated with a pronounced reduction in the insulin secretion response to intravenous tolbutamide as compared with the control studies (Table II). The average total insulin secretion was significantly reduced during the methoxamine infusion both at 10 minutes $(P<0.01)$ and at 30 minutes $(P<0.01)$ (Fig. 1, Table III). The changes in blood glucose concentration during the control insulin secretion test and also during the methoxamine infusion were not significantly correlated with the changes in insulin output. During the control study the blood glucose concentration was reduced by $54 \%$ at 30 minutes after the tolbutamide injection $(P<0.001)$. Though during the methoxamine infusion the reduction in blood glucose concentration after tolbutamide was $35 \%$ of the control value $(P<0.02)$, the difference in response was not statistically significant $(\mathbf{P}>\mathbf{0} \cdot \mathbf{1})$.
(2) Alpha-receptor Blockade.-In both normal subjects the infusion of phentolamine was associated with a considerable increase in the insulin secretion response to tolbutamide (Table II), the average total insulin secretion being significantly increased both at 10 minutes $(P<0.001)$ and at 30 minutes $(P<0.001)$ (Fig. 1, Table III). The changes in blood glucose concentration during the insulin secretion test in the control study and during the phentolamine infusion did not correlate with the changes in insulin output. During the control study the blood glucose concentration was reduced by $43 \%$ $(\mathrm{P}<0.05)$ during the 30 minutes after the tolbutamide injection. During the phentolamine infusion the reduction in blood glucose concentration after tolbutamide was $40 \%(\mathrm{P}<0.05)$;

TABLE III.-Effect of Sympathetic and Parasympathetic Stimulation and Blockade on Insulin Secretion in Alormal Subjects

\begin{tabular}{|c|c|c|c|c|}
\hline \multirow{2}{*}{\multicolumn{3}{|c|}{ Patient Group }} & \multicolumn{2}{|c|}{ Insulin Output (Unit/ml.min.) } \\
\hline & & & 10 Minutes & 30 Minutes \\
\hline $\begin{array}{l}\text { Control } \\
\alpha-S t i m u l a t i o n\end{array}$ & $\because$ & . & $\begin{array}{r}1.11 \pm 0.450(0.895) \\
+0.30 \pm 0.157(0.315) \\
\end{array}$ & $\begin{array}{r}2.37 \pm 0.830(1.670) \\
+0.59 \pm 0.278(0.557) \\
\end{array}$ \\
\hline $\begin{array}{l}\text { Control } \\
\alpha \text {-Blockade }\end{array}$ & . & $\begin{array}{l}\cdots \\
\cdots \\
\end{array}$ & 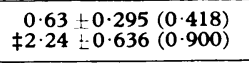 & $\begin{array}{r}1.46 \pm 0.835(0.590) \\
\ddagger 5.13 \pm 1.854(2.622) \\
\end{array}$ \\
\hline $\begin{array}{l}\text { Control a. } \\
\beta \text {-Stimulation }\end{array}$ & . & $\begin{array}{l}\cdots \\
\cdots\end{array}$ & $\begin{array}{r}0.88 \doteqdot 0.042(0.061) \\
\ddagger 2.79 \ddagger 0.605(0.856) \\
\end{array}$ & $\begin{array}{r}1.53 \pm 0.511(0.723) \\
\mp 6.50 \pm 0.969(1.371) \\
\end{array}$ \\
\hline $\begin{array}{l}\text { Control } \\
\beta \text {-Blockade }\end{array}$ & $\begin{array}{l}\cdots \\
\cdots\end{array}$ & $\begin{array}{l}\cdots \\
\cdots\end{array}$ & $\begin{array}{r}2.92 \pm 1.219(2.438) \\
\ddagger 1.39 \pm 0.814(1.627) \\
\end{array}$ & $\begin{array}{r}6.17 \pm 2.488(4.976) \\
\ddagger 3.53 \pm 2.203(2.815) \\
\end{array}$ \\
\hline $\begin{array}{l}\text { Control } \\
\text { Methacholine }\end{array}$ & $\begin{array}{l}\cdots \\
\cdots\end{array}$ & $\begin{array}{l}\cdots \\
\cdots\end{array}$ & $\begin{array}{l}0.78 \pm 0.291(0.582) \\
0.77 \pm 0.178(0.357) \\
\end{array}$ & $\begin{array}{l}1.72 \pm 0.454(0.900) \\
1.50 \pm 0.529(0.857) \\
\end{array}$ \\
\hline $\begin{array}{l}\text { Control ... } \\
\text { Atropine . }\end{array}$ & $\because$ & $\therefore$ & $\begin{array}{l}0.78+0.291(0.582) \\
0.83+0.298(0.597)\end{array}$ & $\begin{array}{l}1.72 \pm 0.454(0.900) \\
1.55 \pm 0.648(1.300)\end{array}$ \\
\hline
\end{tabular}

Data expressed as mean $\$$ variance of mean with standard deviation of observations

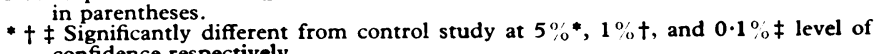
confidence respectively. 
the difference in response was not statistically significant $(\mathrm{P}>0.9)$.

(3) Beta-receptor Stimulation.-In both normal subjects the infusion of isoprenaline was associated with a considerable increase in the insulin secretion response to tolbutamide (Table II), the average total insulin secretion being significantly increased at both 10 minutes $(\mathrm{P}<0.001)$ and 30 minutes $(P<0.001)$ (Fig. 1, Table III). The reduction of $60 \%$ $(\mathrm{P}<0.001)$ in blood glucose concentration during the control insulin secretion test reflected the increase in insulin output after tolburamide. Despite the significantly increased secretion of insulin during isoprenaline infusion the blood glucose concentration increased by $6 \%$. This difference in response was statistically significant $(\mathrm{P}<0.001)$.

(4) Beta-receptor Blockade.-In all four normal subjects the intravenous injection of propranolol was associated with a pronounced reduction in the insulin secretion response to intravenous tolbutamide as compared with the control studies (Table II). The average total insulin output was significantly reduced by propranolol both at 10 minutes $(P<0.001)$ and at 30 minutes $(\mathrm{P}<0.001)$ (Fig. 1, Table III). The changes in blood glucose concentration during the control insulin secretion test and after beta-blockade were not significantly correlated with the changes in insulin output. During the control study the blood glucose concentration was reduced by $40 \%$ $(P<0.05)$ in the 30 minutes after the injection of tolbutamide. After propranolol the reduction in blood glucose concentration during the insulin secretion test was a quarter of the control value $(\mathrm{P}<0.05)$; this difference in response was not statistically significant $(P>0.8)$.

(5) Comparison of alpha-blockade and beta-stimulation.-In one normal subject the comparative effects of phentolamine and isoprenaline on the facility with which insulin was released by tolbutamide were studied sequentially. In this subject both alpha-blockade and beta-stimulation increased the insulin secretion response to intravenous tolbutamide, but isoprenaline was the most effective (Fig. 2). The insulin secretion response during phentolamine infusion was significantly greater than during the control study both at 10 minutes $(P<0.01)$ and at 30 minutes $(P<0.05)$. Similarly the insulin secretion response during isoprenaline infusion was significantly greater at 10 minutes $(\mathrm{P}<0.001)$ and at 30

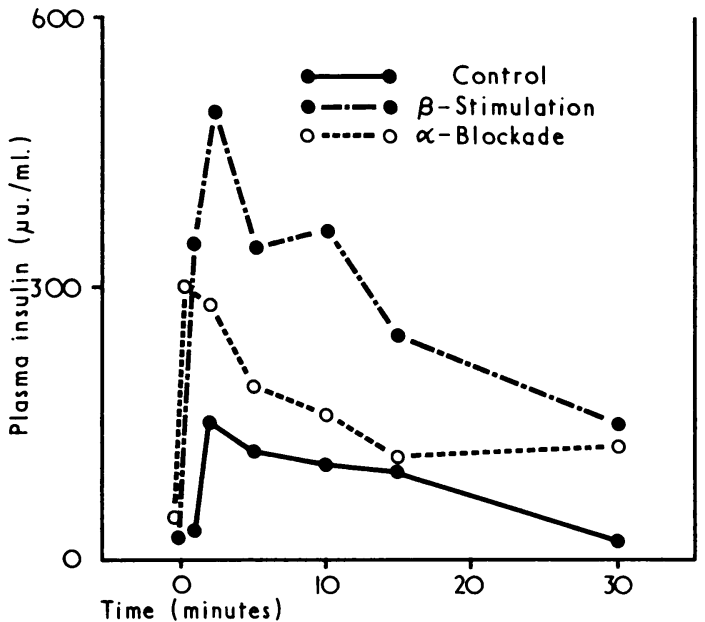

FIG. 2.-Comparative effects of sympathetic stimulation and blockade on the insulin secretion response to intravenous tolbutamide in a normal subject.

minutes $(P<0.001)$ than during the control study. The insulin secretion response during isoprenaline infusion was significantly greater than that during phentolamine infusion both at 10 minutes $(P<0.001)$ and at 30 minutes $(P<0.001)$.

(6) Parasympathetic Stimulation.-In all four normal subjects the intravenous injection of methacholine was not associated with any significant change in the insulin secretion response to intravenous tolbutamide (Table II). The reductions in blood glucose concentration during the insulin secretion test before and after methacholine were of a similar order-namely, 49\% $(\mathrm{P}<0.01)$ and $41 \% \quad(\mathrm{P}<0.01)$, respectively, this difference in response was not statistically significant $(\mathrm{P}<0.4)$.

(7) Parasympathetic Blockade.-In all four normal subjects the intravenous injection of atropine was not associated with any significant change in the insulin secretion response to intravenous tolbutamide (Table II). The reductions in blood glucose concentration during the insulin secretion test before and after atropine were of a similar order-namely, $49 \%$ $(\mathrm{P}<0.01)$ and $38 \%,(\mathrm{P}<0.01)$, respectively; this difference in response was not statistically significant $(P>0.3)$.

TABle IV.-Summarized Data of Insulin-secretion Test in Patients in Heart Failure (Insulin in $\mu \mathrm{u} . / \mathrm{ml} . \mathrm{Glucose}$ in mg./100 ml.)

\begin{tabular}{|c|c|c|c|c|c|c|c|c|}
\hline & \multicolumn{7}{|c|}{ Time (Minutes) after Injection of Tolbutamide } \\
\hline & & 0 & 1 & 2 & 5 & 10 & 15 & 30 \\
\hline \multirow{2}{*}{ Control (4) } & $\{$ Insulin $\ldots$ & $50 \pm 19(19)$ & $72 \pm 27(55)$ & $80 \pm 29(57)$ & $131 \pm 40(80)$ & $161 \pm 37(73)$ & $165 \pm 38(77)$ & $163 \pm 54(109)$ \\
\hline & | Glucose ... & $93 \pm 14(28)$ & $98+16(32)$ & $97 \pm 15(30)$ & $98 \leftarrow 16(33)$ & $97 \pm 18(35)$ & $92 \pm 18(37)$ & $76 \pm 15(29)$ \\
\hline \multirow{2}{*}{ a-Blockade } & $\{$ Insulin $\ldots$ & $71 \pm 14(27)$ & $174+24(47)$ & $206 \pm 29(58)$ & $212 \vdash 43(86)$ & $208 \pm 45(90)$ & $243+72(149)$ & $236 \pm 69(139)$ \\
\hline & Glucose . & $97 \pm 7(15)$ & $104 \pm 12(24)$ & $97+10(20)$ & $95 \pm 9(18)$ & $94 \pm 10(20)$ & $91 \pm 10(19)$ & $85 \pm 10(20)$ \\
\hline \multirow{2}{*}{ Control (2) } & $\{$ Insulin $\ldots$ & $24 \pm 7(9)$ & $48 \pm 7(9)$ & $127 \pm 68(95)$ & $101 \pm 43(60)$ & $96 \pm 6(8)$ & $82 \pm 4(6)$ & $83 \pm 18(25)$ \\
\hline & Glucose .. & $85 \pm 0.5(1)$ & $89+14(20)$ & $89 \div 12(17)$ & $87 \pm 12(17)$ & $87 \pm 11(15)$ & $81 \pm 15(21)$ & $65 \pm 11(15)$ \\
\hline \multirow{2}{*}{$\boldsymbol{\beta}$-Stimulation } & $\{$ Insulin $\ldots$ & $50 \pm 10(13)$ & $162+3(4)$ & $196 \pm 55(77)$ & $214 \pm 83(117)$ & 194 & $172 \pm 70(90)$ & $144 \pm 53(74)$ \\
\hline & Glucose .. & $99 \pm 19(26)$ & $105 \pm 23(32)$ & $108 \pm 20(28)$ & $107+20(28)$ & $112 \pm 14(19)$ & $110 \pm 12(16)$ & $110 \pm 6(8)$ \\
\hline \multirow{2}{*}{ Control (1) } & $\left\{\begin{array}{l}\text { Insulin } \ldots \\
\text {. }\end{array}\right.$ & 30 & 54 & 59 & 58 & 90 & 86 & 100 \\
\hline & Glucose .. & 85 & 103 & 101 & 99 & 97 & 96 & 75 \\
\hline \multirow{2}{*}{$\alpha$-Blockade } & $\left\{\begin{array}{l}\text { Insulin } \ldots \\
\text {. }\end{array}\right.$ & 52 & 144 & 172 & 130 & 109 & 87 & 87 \\
\hline & ¿Glucose .. & 107 & 110 & 100 & 106 & 111 & 109 & 102 \\
\hline \multirow{2}{*}{$\beta-S t i m u l a t i o n$} & $\{$ Insulin $\ldots$ & 40 & 159 & 141 & 131 & 118 & 102 & 91 \\
\hline & Glucose .. & 117 & 127 & 127 & 127 & 125 & 121 & 115 \\
\hline \multirow{2}{*}{ Control (1) } & $\{$ Insulin $\ldots$ & 17 & 41 & 194 & 143 & 101 & 78 & 65 \\
\hline & Glucose .. & 84 & 75 & 77 & 75 & 76 & 66 & 54 \\
\hline $\begin{array}{c}\text { a-Blockade } \\
+\end{array}$ & $\{$ Insulin $\ldots$ & 167 & 270 & 289 & 342 & 340 & 338 & 268 \\
\hline B-Stimulation & Glucose .. & 79 & 73 & 71 & 70 & 73 & 68 & 74 \\
\hline
\end{tabular}

Number of patients in each study in parentheses. Data expressed as mean + variance of mean with standard deviation of observations in parentheses. 


\section{Studies in Patients in Heart Failure}

(1) Alpha-receptor Blockade.-In four patients in severe heart failure the infusion of phentolamine was associated with a considerable increase in the insulin secretion response to tolbutamide (Table IV), the average total insulin secretion being significantly increased both at 10 minutes $(P<0.05)$ and at 30 minutes $(\mathrm{P}<0.01)$ (Fig. 1, Table $\mathrm{V})$. The changes in blood glucose concentration were not significantly correlated with the changes in insulin secretion. During the control study the blood glucose concentration fell by only $18 \%$, reflecting the reduced insulin secretion response in these patients. During alpha-receptor blockade the injection of tolbutamide was followed by a fall in blood glucose concentration of only $12 \%$ in spite of an increased secretion of insulin. This difference in response is not statistically significant $(P>0 \cdot 6)$.

TABle V.-Effect of Sympathetic and Parasympathetic Stimulation and Blockade on Insulin Secretion in Heart Failure

\begin{tabular}{|c|c|c|c|c|}
\hline \multirow{2}{*}{\multicolumn{3}{|c|}{ Patient Group }} & \multicolumn{2}{|c|}{ Insulin Output (Unit/ml.min.) } \\
\hline & & & 10 Minutes & 30 Minutes \\
\hline $\begin{array}{l}\text { Control } \\
\alpha \text {-Blockade }\end{array}$ & . & $\cdots$ & $\begin{array}{r}0.79 \pm 0.321(0.643) \\
* 1.28 \pm 0.254(0.508)\end{array}$ & $\begin{array}{r}2.93+0.824(1.649) \\
+4.58+1.321(2.642)\end{array}$ \\
\hline $\begin{array}{l}\text { Control } \\
\beta-S t i m u l a t i o n\end{array}$ & $\begin{array}{l}\cdots \\
\cdots\end{array}$ & $\begin{array}{l}\cdots \\
\cdots\end{array}$ & $\begin{array}{r}0.72+0.374(0.529) \\
+1.72+0.839(1.187)\end{array}$ & $\begin{array}{r}1.93+0.351(0.497) \\
+4.15+2.388(3.378) \\
\end{array}$ \\
\hline $\begin{array}{l}\text { Control } \\
\alpha \text {-Blockade } \\
\beta-\text { Stimulation }\end{array}$ & $\begin{array}{l}. . \\
\cdots\end{array}$ & $\begin{array}{l}\cdots \\
\cdots\end{array}$ & $\begin{array}{r}0.35 \\
* 0.79 \\
* 0.88\end{array}$ & $\begin{array}{l}1.58 \\
1.53 \\
1.76\end{array}$ \\
\hline $\begin{array}{l}\text { Control } a \\
\alpha \text {-Blockade }+ \\
\beta-S t i m u l a t i o\end{array}$ & $\begin{array}{l}. \\
\text { n.. }\end{array}$ & $\begin{array}{l}\cdots \\
\ldots\end{array}$ & $\begin{array}{r}1.09 \\
+1.48\end{array}$ & $\begin{array}{r}2 \cdot 28 \\
\ddagger 4 \cdot 38\end{array}$ \\
\hline
\end{tabular}

Data expressed as mean \pm variance of mean with standard deviation of observations * $\dagger \ddagger$ Significantly different from control study at $5 \% *, 1 \% \dagger$, and $0 \cdot 1 \% \ddagger$ level of Fonfidence respectively.
conificantly different

(2) Beta-receptor Stimulation.-In two patients in severe heart failure the infusion of isoprenaline was followed by a pronounced increase in the insulin secretion response to tolbutamide (Table IV), the average total insulin output being significantly increased both at 10 minutes $(P<0.01)$ and at 30 minutes $(P<0.001)$ (Fig. 1, Table V). The changes in blood glucose concentration did not correlate with the changes in insulin output; as in the normal subjects during isoprenaline infusion, the changes in insulin and glucose were opposed. The blood glucose concentration fell by $24 \%$ during the 30 minutes of the control insulin secretion test. Despite the fact that the blood insulin concentration was considerably greater, the blood glucose concentration increased by $10 \%$ during isoprenaline infusion. This difference in response is statistically significant $(\mathrm{P}<0.05)$.

(3) Comparison of alpha-blockade and beta-stimulation.-In one patient the comparative effects of phentolamine and isoprenaline on the facility with which insulin was released by tolbutamide were studied sequentially. In this patient both alpha-blockade and beta-stimulation increased the insulin secretion response to intravenous tolbutamide equally (Table IV). Compared with the control study the insulin secretion responses at 10 minutes were significantly increased by both drugs at the $5 \%$ confidence level (Table V). There was no significant difference between the two drugs and the control observations at $\mathbf{3 0}$ minutes in this patient.

(4) Combined alpha-blockade and beta-stimulation.-In one patient the control insulin secretion test was compared with that during beta-stimulation alone and that during combined alpha-blockade and beta-stimulation, the tests being carried out on three consecutive days (Fig. 3, Table IV). Betastimulation with isoprenaline resulted in a pronounced increase in the insulin secretion response, the total insulin secretion being significantly increased both at 10 minutes $(P<0.001)$ and at 30 minutes $(P<0.001)$ compared with the

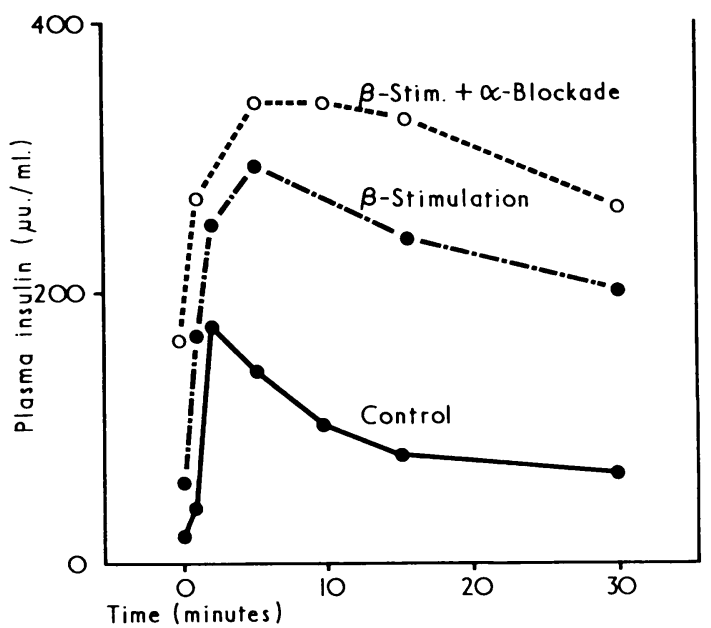

Fig. 3. - Comparative effects of sympathetic stimulation and blockade on the insulin secretion response to intravenous tolbutamide in a patient in severe heart failure.

control study. The combined infusion of phentolamine and isoprenaline on day 3 increased the plasma concentration of insulin, but the total response to intravenous tolbutamide was no greater than that to isoprenaline alone (Fig. 1). The total insulin secretion response during the combined infusion was significantly greater than that of the control study both at $\mathbf{1 0}$ minutes $(P<0.05)$ and at 30 minutes $(P<0.001)$. But comparison of the results of the combined infusion with that of isoprenaline alone showed no significant difference at either 10 or 30 minutes.

\section{Discussion}

These studies confirm and extend the evidence for the important part played by the sympathetic nervous system in the regulation of insulin secretion in man, and particularly in patients in severe heart failure. The validity and significance of the qualitative changes observed are further increased by the consistency of the observations between subjects and by their serial demonstration in the same individual.

The role of the sympathetic nervous system in the control of insulin secretion in these studies is clear. Alpha-receptor blockade and beta-receptor stimulation significantly potentiated the facility with which insulin was released from the pancreas, while alpha-stimulation and beta-blockade suppressed insulin release. The influence of the sympathetic nerves on insulin release is further emphasized by the semiquantitative differences in the insulin secretion response during alpha-blockade and beta-stimulation in normal subjects and patients with heart failure. In the same normal subject alpha-blockade was much less effective than beta-stimulation in potentiating insulin secretion whereas in heart failure phentolamine and isoprenaline appeared to be of about equal effectiveness. This difference in response is probably related to the greatly increased sympathetic drive, particularly alphareceptor stimulation, present in patients in heart failure, so that alpha-blockade could be expected to produce a much greater effect in such patients than in resting normal subjects, in whom alpha-stimulation is not usually increased.

These pharmacologically induced changes confirm earlier evidence for the direct sympathetic nervous control of insulin secretion. Both adrenaline and noradrenaline inhibit insulin release from the pancreatic beta-cells in vitro (Coore and Randle, 1964; Malaisse et al., 1967) and in vivo both in animals (Hertelendy et al., 1966; Kris et al., 1966; Altszuler et al., 1967) and in man (Karam et al., 1966; Porte et al., 1966; Porte and Williams, 1966). Excessive secretion of endogenous catecholamines in patients with phaeochromocytoma is associated with inhibition of insulin secretion (Wilber et al., 
1966; Spergel et al., 1968; Colwell, 1969; Porte, 1969); alphaadrenergic blocking agents rapidly and completely reverse this inhibition (Porte, 1969). Infusion of catecholamines into the pancreatic artery of the dog has been shown to result in severe histological changes confined to the beta-cells; blockade of the sympathetic nerves with dihydroergotamine protected the beta-cells completely against these catecholamine-induced changes (Loubatières et al., 1965). This evidence, together with that from the present studies, would suggest that the sympathetic nervous system has an important and sometimes overriding control of insulin secretion.

Though many factors may regulate insulin secretion, the dominating control exercised by the sympathetic nervous system is seen in a number of clinical situations. In patients with greatly increased sympathetic nervous activity due to cardiogenic shock (Allison et al., 1969; Taylor et al., 1969), severe heart failure (Sharma et al., 1970), hypothermia (Baum and Porte, 1968), and phaeochromocytoma (Wilber et al., 1966; Spergel et al., 1968; Colwell, 1969; Porte, 1969) the secretion of insulin is completely suppressed even though the blood glucose concentration is greatly raised. The insulin suppression in these patients is maintained even when challenged by such a potent insulinogenic stimulus as intravenous tolbutamide (Taylor et al., 1969; Majid et al., 1970; Sharma et al., 1970).

The role of the parasympathetic nervous system in the control of insulin secretion has been much less thoroughly investigated. Claims that carbonylcholine and acetylcholine with eserine stimulated insulin secretion in vitro (Malaisse et al., 1967) have not been confirmed (Coore and Randle, 1964). Though direct stimulation of the vagus nerve in intact animals has been reported to result in an increased secretion of insulin (Daniel and Henderson, 1967; Frohman et al., 1967; Kaneto et al., 1967; Findlay et al., 1969) no imoairment of insulin secretion occurs after vagotomy in man (Frohman et al., 1967). Our studies would also suggest that the parasympathetic nerves extend little direct control over insulin secretion in normal man.

It may be argued that the changes in insulin secretion observed in these investigations simply reflected changes in cardiac output and splanchnic blood flow induced by the drugs used. Though the cardiac output and regional blood flow are increased both by phentolamine (Taylor et al., 1965a) and by isoprenaline (Weissler et al., 1959), other evidence would suggest that these effects were not solely responsible for the changes observed. Mendlebaum and Morgan (1968), using cardiac bypass in dogs to eliminate the effect of drugs on the cardiac output, demonstrated that the sympathetic nerves had a direct effect on the secretion of insulin independent of changes in cardiac output. Both nicotinic acid (Svedmyr, 1967) and aminophylline (Rees et al., 1969) cause a generalized vasodilatation similar to that resulting from phentolamine (Taylor et al., 1965b), but their administration does not result in any increase in insulin secretion (Porte, 1967; Cerasi et al., 1969). Beta-adrenergic blockade with propranolol results in a reduction in cardiac output (Ulrych $e t$ al. 1968; Tavlor et al., 1970c) and a reduction in splanchnic blood flow (Price et al., 1967). These reductions in cardiac output and splanchnic blood flow, however, are relatively small in normal supine resting man, and it is unlikely that the reduction in splanchnic blood flow alone could have accounted for the large reductions in insulin secretion observed in our normal subjects after beta-blockade. Thus while changes in splanchnic blood flow may possibly indirectly affect the secretion of insulin, the evidence strongly implicates the predominant role of the sympathetic nerves in the control of the islet beta-cells. It is probably not fortuitous that these cells are abundantly supplied with both cholinergic and adrenergic autonomic nerve endings (Esterhuizen et al., 1968).

The clinical implications of these findings are of considerable therapeutic importance. The failing and anoxic heart derives the major part of its energy requirements from the metabolism of glucose (Scheuer, 1967; Cascarano et al., 1968; Weissler et al., 1968; Owen et al., 1969). Insulin is essential for the normal metabolism of glucose, so that the suppression of insulin secretion accompanying severe heart failure is of serious import. In the present study both phentolamine and isoprenaline produced a rapid and significant improvement in the insulin secretion response of such patients. Clinical attention in the past has been largely directed to the haemodynamic aspects of the use of these two drugs in the low cardiac output state associated with cardiogenic shock after myocardial infarction or open-heart surgery. The present observations add additional emphasis to their possible metabolic benefits in any pumping failure of the heart.

We thank the normal volunteers who consented to these studies; Sisters F. Ellis, R. Cox, and S. Winterburn for their help and cooperation; Mr. L. Bulusu, of the M.R.C. Mineral Metabolism Unit, for statistical advice and help; Dr. C. J. Hayter, department of nuclear medicine at the General Infirmary, Leeds, for the use of the Philips counter; and Sir Ronald Tunbridge and Professor R. J. Linden for their encouragement throughout. This work was supported by a grant from the Leeds and West Riding Medical Research Trust.

Requests for reprints should be addressed to Dr. S. H. Taylor, Department of Medicine, The General Infirmary, Leeds LS1 3EX.

REFERENCES

Allison, S. P., Chamberlain, M. J., and Hinton, P. (1969). British Medical Fournal, 4, 776.

Altszuler, N., Steel, R., Rathgeb, I., and De Bodo, R. C. (1967). American fournal of Physiology, 212, 677.

Baum, D., and Porte, D. (1968). Diabetes, 17, 298.

Cascarano, J., Chick, W. L., and Siedman, I. (1968). Proceedings of the Society for Experimental Biology and Medicine, 127, 25.

Cerasi, E., Effendic, S., and Luft, R. (1969). Lancet, 2, 301.

Colwell, J. A. (1969). Annals of Internal Medicine, 71, 251.

Coore, H. G., and Randle, P. J. (1964). Biochemical fournal, 93, 66

Daniel, P. M., and Henderson, J. R. (1967). Fournal of Physiology, 192, 317 Esterhuizen, A. C., Spriggs, T. L. B., and Lever, J. D. (1968). Diabetes, $17,33$.

Findlay, J. A., Gill, J. R. Lever, D. J., Randle, P. J., and Spriggs, T. L. B (1969). Fournal of Anatomy, 104, 580

Fisher, R. A. (1946). Statistical Methods for Research Workers, 10th edn. Edinburgh, Oliver and Boyd.

Frohman, L. A., Ezdinli, E. Z., and Rouhollah, J. (1967). Diabetes, 16, 443. Hales, C. N., and Randle, P. J. (1963). Biochemical fournal, 88, 137.

Hertelendy, F., Machlin, L. J., Gordon, R. S., Horino, M., and Kipnis, D. M. (1966). Proceedings of the Society for Experimental Biology and Medicine, 121, 675.

Jose, A. D., and Taylor, R. R. (1969). Fournal of Clinical Investigation, 48, 2019.

Kaneto, A., Kosaka, K., and Nakao, K. (1967). Endocrinology, 80, 530.

Karam, J. H., Grasso, S. G., Wegienka, L. C., Grodsky, G. M., and Forsham P. H. (1966). Diabetes, 15, 571 .

Koelle, G. B. (1965). In The Pharmacological Basis of Therapeutics, ed L. S. Goodman, and A. Gilman, 3rd edn., p. 464. New York, Macmillan Kris, A. O., Miller, R. E., Wherry, F. E., and Mason, J. W. (1966). Endocrinology, 78,87 .

Loubatières, A., et al. (1965). Diabetologia, 1, 13.

Maingay, D., et al. 1967). Lancet, 1, 361.

Majid, P. A., et al. (1970). British Heart fournal. In press.

Malaisse, W., Mallaisse-Lagae, F., Wright, P. H., and Ashmore, J. (1967). Endocrinology, 80, 975 .

Mendlebaum, I., and Morgan, C. R. (1968). Diabetes, 17, 333

Morley, G., Dawson, A., and Marks, V. (1968). Proceedings of the Association of Clinical Biochemists, 5, 43.

Owen, P., Thomas, M., and Opie, L. (1969). Lancet, 1, 1187.

Owen, P., Thomas, M., and Opie, L. (1969). Lancet, 1, 1187.
Payne, R. A., and Kay, A. W. (1962). Clinical Science, 22, 373.

Payne, R. A., and Kay, A. W. (1962). Clinical Science, 22,

Porte, D. (1967). Fournal of Clinical Investigation, 46, 86.

Porte, D. (1969). Archives of Internal Medicine, 123, 252. Clinical Investigation, 45, 228 .,

Porte, D., and Williams, R. H. (1966). Science, 152, 1248.

Price, H. L., Cooperman, L. H., and Warden, J. C. (1967). Circulation Research, 21, 333.

Rees, H. A., MacDonald, H. R., Borthwick, R. G., Muir, A. L., and Donald, K. W. (1969). Clinical Science, 36, 359.

Saxton, C., Dykes, J. R. W., Majid, P. A., and Taylor, S. H. (1970). Clinical Science. In press.

Scheuer, J. (1967). American fournal of Cardiology, 19, 385.

Seltzer, H. S. (1962). Fournal of Clinical Investigation, 41, 229.

Sharma, B., Majid, P. A., Pakrashi, B. C., Dykes, J. R. W., and Taylor, S. H. (1970). British Medical Fournal, 396. 
Spergel, G., Bleichncr, S. J., and Ertel, N. H. (1968). Nere England fournal of Medicine, 278, 803 .

Svedmyr, N. (1967). Acta Pharmacologica et Toxicologica, 25, Suppl. No. 4, p. 29.

Taylor, S. H., et al. (1969). Lancet, 2, 1373.

Taylor, S. H., Majid, P. A., and Sharma, P. (1970a). Postgraduate Medical fournal. In press.

Taylor, S. H., et al. (1970b). British Heart fournal. In press.

Taylor, S. H., Majid, P. A., Saxton, C., and Stoker, J. B. (1970c). Neqv Zealand Medical fournal. In press.
Taylor, S. H., Sutherland, G. R., Mackenzie, G. J., Staunton, H. P., and Donald, K. W. (1965a). Circulation, 31, 741.

Taylor, S. H., Sutherland, G. R., Mackenzie, G. J., Staunton, H. P., and Donald, K. W. (1965b). Clinical Science, 28, 265.

Ulrych, M., Frohlich, E. D., Dustan, H. P., and Page, I H. (1968). Circulation, 37 ., Froh

Weissler, A. M., et al. (1968). Fournal of Clinical Investigation, 47, 403.

Weissler, A. M., Leonard, J. J., and Warren, J. V. (1959). fournal of Labora tory and Clinical Medicine, 53, 921

Wilber, J. I., Turtle. J. R., and Crane, N. A. (1966). Lancet, 2, 733

\title{
Further Observations on the Diurnal Variation in Oral Glucose Tolerance
}

\author{
R. J. JARRETT, ${ }^{*}$ M.D. ; H. KEEN, $†$ M.B., M.R.C.P.
}

\begin{abstract}
Summary: Diurnal variation in oral glucose tolerance was studied in 122 male volunteers aged 40 years and over who participated in a screening health examination. In those with screening blood sugar levels exceeding $110 \mathrm{mg} . / 100 \mathrm{ml}$. the degree of diurnal variation was least in those with the highest morning glycaemia; the latter also tended to have lower afternoon fasting blood sugar levels.

In a group of 40 control subjects, afternoon glucose tolerance tests yielded significantly higher post-glucose blood sugar levels. The degree of diurnal variation was significantly and inversely related to the degree of obesity.
\end{abstract}

\section{Introduction}

The phenomenon of diurnal variation of glucose tolerance in man has been described by several authors (Roberts, 1964; Bowen and Reeves, 1967; Jarrett and Keen, 1969), but little is known about the factors influencing this variation or about its relation to pathological carbohydrate intolerance and diabetes mellitus. We have taken the opportunity provided by a recent health survey of London civil servants to examine further some of the related factors.

\section{Methods}

The health survey, conducted in conjunction with the Department of Medical Statistics and Epidemiology, London School of Hygiene and Tropical Medicine, was open to male civil servants aged 40 and over and working in various Government departments in London. Volunteers were seen between 9.30 a.m. and 1 p.m., having fasted overnight and having drunk $50 \mathrm{~g}$. of liquid glucose $(235 \mathrm{ml}$. of Lucozade) one hour and fifty minutes before attending the screening clinic. Two hours after taking the glucose drink a capillary blood sample $(0.1 \mathrm{ml}$.) was taken from the ear lobe and added to $0.9 \mathrm{ml}$. of $1 \%$ potassium fluoride, and the blood sugar was estimated by the ferricyanide reduction micro-method (Technicon method $\mathrm{N}-9 \mathrm{a}$ ) on the AutoAnalyzer.

The usual survey practice was to carry out standard oral glucose tolerance tests on subjects with screening blood sugar levels of $110-199 \mathrm{mg} . / 100 \mathrm{ml}$. and to refer those with levels of $200 \mathrm{mg} . / 100 \mathrm{ml}$. or more to their personal doctors. For a period of about six months, however, all those with screening levels of $110 \mathrm{mg} . / 100 \mathrm{ml}$. or more, including those exceeding $200 \mathrm{mg} . / 100 \mathrm{ml}$, were recalled for a full glucose tolerance test; they were further asked if they would consent to a second test for the present research project. Though most $(96 \%)$ consented to the second test, difficulties in arranging convenient appointments reduced the overall response to $85 \%$ (122 subjects).

A random sample of subjects with screening blood sugars below $110 \mathrm{mg} . / 100 \mathrm{ml}$., stratified for age and two-hour blood sugar level, was selected as a control group, and those concerned were asked to participate in the research project Replies were received from 68 of the 81 people approached. Twenty-eight of these were either unable or unwilling to participate, so that $\mathbf{4 0}$ subsequently had the two glucose tolerance tests.

The morning and afternoon tests were performed in random order not less than three or more than seven days apart and after three days of supplementation of the normal daily diet with an extra $150 \mathrm{~g}$. of carbohydrate. The morning test began, after an overnight fast, at 9.30 a.m. The afternoon test started at 4 p.m., the subjects having fasted since a light breakfast, which in most cases had been completed by 8 a.m. Capillary blood samples were obtained before a $50 \mathrm{~g}$. load of liquid glucose and subsequently at half-hourly intervals for two hours. Subjects remained seated and did not smoke during the test period. Blood sugars were estimated as before.

The area under the glucose tolerance curve was calculated from the formula: area $=a+2 b+2 c+2 d+e$, where $a$ is the fasting blood sugar and $b-e$ are the subsequent blood sugar values.

In addition, the possible influence of diurnal variation on screening blood sugar values was examined. Those attending the usual morning survey sessions for a one-week period in January 1970 were asked to volunteer for an extra afternoon screening test, when two-hour blood sugars were estimated on samples collected between 5 and 6 p.m., the glucose having been drunk after fasting from breakfast. In this study, for which no special dietary preparations were made, 107 men participated.

\section{Results}

\section{Control Group}

The mean glucose tolerance test results are presented in Table I. The results are similar to, though not identical with, those in our earlier "normal" sample (Jarrett and Keen, 1969), which, however, was younger, was composed of both sexes, and in which the afternon tests were performed at 1 p.m., after a shorter, four to five hours, fast. In both studies the fasting blood sugar values, morning and afternoon, were virtually identical. In the previous series a significant excess of afternoon over morning values was already apparent 30 minutes after the glucose load, was numerically greater at 60 and 90 minutes, but was less at 120 minutes. In the present study there was little difference between morning and afternoon values at 30 minutes, but there was still a considerable and significant difference at 120 minutes. 